\title{
Cyberlindnera jadinii yeast as a protein source in early- to mid-lactation dairy cow diets: Effects on feed intake, ruminal fermentation, and milk production
}

\author{
Alemayehu Kidane, ${ }^{1} \odot$ Stine Gregersen Vhile, ${ }^{1} \odot$ Sabine Ferneborg, ${ }^{1} \odot$ Siv Skeie, ${ }^{2 *} \odot$ Martine Andrea \\ Olsen, ${ }^{2}$ (D) Liv Torunn Mydland, ${ }^{1}$ (D) Margareth $\varnothing v e r l a n d,{ }^{1}$ (D) and Egil Prestløkken ${ }^{1}$ (i) \\ ${ }^{1}$ Faculty of Biosciences, Norwegian University of Life Sciences, N-1432 Ås, Norway \\ ${ }^{2}$ Faculty of Chemistry, Biotechnology and Food Science, Norwegian University of Life Sciences, N-1432 Ås, Norway
}

\begin{abstract}
We examined the effects of substituting soybean meal with either yeast protein from Cyberlindnera jadinii or barley in concentrate feeds on feed intake, ruminal fermentation products, milk production, and milk composition in Norwegian Red (NRF) dairy cows. The concentrate feeds were prepared in pellet form as soy-based (SBM; where soybean meal is included as a protein ingredient), yeast-based (YEA; soybean meal replaced with yeast protein), or barley-based (BAR; soybean meal replaced with barley). The SBM contained $7.0 \%$ soybean meal on a dry matter (DM) basis. This was replaced with yeast protein and barley in the YEA and BAR concentrate feeds, respectively. A total of 48 early- to mid-lactation [days in milk \pm standard deviation (SD): $103 \pm 33.5 \mathrm{~d}] \mathrm{NRF}$ cows in their first to fourth parity and with initial milk yield of $32.6 \mathrm{~kg}$ (SD $=7.7$ ) were allocated into 3 groups, using a randomized block design, after feeding a common diet [SBM and good-quality grass silage: crude protein $(\mathrm{CP})$ and neutral detergent fiber (NDF) content of 181 and $532 \mathrm{~g} /$ $\mathrm{kg}$ of DM, respectively] for $14 \mathrm{~d}$ (i.e., covariate period). The groups $(\mathrm{n}=16)$ were then fed one of the dietary treatments (SBM, YEA, or BAR) for a period of $56 \mathrm{~d}$ (i.e., experimental period). The concentrate feeds were offered in split portions from 3 automatic feeders using electronic identification, with ad libitum access to the same grass silage. Dietary treatments had no effect on daily silage intake, total DM intake, or total NDF intake. Dietary CP intake was lower and starch intake was higher in the BAR group compared with the other groups. Ruminal fluid $\mathrm{pH}$, short-chain volatile fatty acid (VFA) concentrations, acetate-to-propionate ratio, and non-glucogenic to glucogenic VFA ratio were not
\end{abstract}

Received January 7, 2021.

Accepted November 9, 2021.

*Corresponding author: siv.skeie@nmbu.no affected by dietary treatments. No effects of the dietary treatments were observed on body weight change, body condition score change, milk yield, energy-corrected milk yield, milk lactose and fat percentages, or their yields. In conclusion, yeast protein can substitute conventional soybean meal in dairy cow diets without adverse effect on milk production and milk composition, given free access to good-quality grass silage.

Key words: amino acid, dietary nitrogen, milk composition, soybean, barley

\section{INTRODUCTION}

Sustainable meat and milk production is essential for future agricultural production. Growing environmental concerns surrounding food and feed production, and sustainability issues due to increasing population and demand for food (Foley et al., 2011; Notarnicola et al., 2017), necessitate the search for local feed resources (Åby et al., 2014). Diets for high-yielding dairy cows in the Nordic countries commonly consist of grass silage (Huhtanen et al., 2013) augmented with concentrate feeds based on barley and a relatively high proportion of imported protein feed ingredients such as soybean meal, corn gluten meal, and rapeseed meal (Åby et al., 2014).

Norway has a challenging climate for agriculture, with a typical grassland of only about $3 \%$ cultivated land and limited potential to grow food crops. Therefore, a growing need exists to develop novel, sustainable, nonfood protein sources that can be used in animal diets to allocate food protein to the increasing human population. Recent efforts, in Norway and elsewhere, have focused on the effects of partial or complete substitution of imported protein ingredients with alternative protein sources in animal feeds (Neal et al., 2014; Dalle Zotte et al., 2019; Cruz et al., 2020a,b). Yeastderived microbial protein is one such emerging protein ingredient, with favorable AA composition in animal feeds (Øverland and Skrede, 2017). With a forest cover of about $38 \%$ of the total land area (Government of 
Norway, 2014) and the country experiencing a large accumulation of forest biomass with steady increase in net growth over the recent years (Solberg et al., 2021), yeast produced using wood biomass can provide highquality protein. For instance, a typical Candida utilis grown on biomass hydrolysate with ammonium sulfate as a nitrogen source (Sharma et al., 2018) had an AA profile comparable to that of soybean meal (Cavins et al., 1972). Sabbia et al. (2012) reported that DEMP - a yeast-derived microbial protein based on Saccharomyces cerevisiae (Alltech Inc.) - had an AA profile similar to that of ruminal microbial protein. As a result, Sabbia et al. (2012) reported that DEMP could replace plant protein in dairy cow diets without negative effects on milk production when used from 1.14 to $3.41 \%$ of the diet DM. Neal et al. (2014) reported a tendency for increased milk production when adding $1.15 \%$ of the diet DM as yeast microbial protein. In addition, Higginson et al. (2017) reported improved metabolic status (e.g., reduced metabolic stress and adipose tissue mobilization) in transition cows during the postpartum period when fed yeast-derived microbial protein. However, Manthey et al. (2016) reported reduced feed efficiency (energy-corrected milk per kilogram of DMI) and milk fat yield for cows fed $2.25 \%$ of diet DM as yeast-derived microbial protein. These studies were based on corn silage and alfalfa forages, in contrast with the Scandinavian grass-based silage, with expected differences in nutrient composition and density. Such differences, especially in the carbohydrate fraction of the diet, would be expected to influence the utilization efficiency of the dietary protein in dairy cow diets (Hristov et al., 2005). Furthermore, the microbial proteins used in these studies were largely based on Saccharomyces cerevisiae, which might differ from other yeasts in the level of CP, AA profile, and other nutrients (Øverland and Skrede, 2017).

We hypothesize that Cyberlindnera jadinii yeast protein can replace soybean meal or barley in early- to mid-lactation Norwegian Red (NRF) dairy cow diets without adverse effects on milk yield and milk composition. The main objective of this study was, therefore, to evaluate the effects of total substitution of soybean meal in concentrate feeds by $C$. jadinii yeast protein in grass silage-based rations of early- to mid-lactation NRF cows on feed intake, ruminal fermentation parameters, milk yield, and milk composition. Furthermore, as barley can be produced in Norway and is the most used concentrate feed ingredient, a diet with barley replacing both yeast protein and soybean meal in the concentrate feed was compared against those 2 protein sources.

\section{MATERIALS AND METHODS}

\section{Experimental Animals, Diets, and Design}

This experiment was performed at the Livestock Production Research Center of the Norwegian University of Life Sciences (Ås, Norway), with all animal procedures approved by the national animal research authority of the Norwegian Food Safety Authority (FOTS ID no. 18038).

A total of $48 \mathrm{NRF}$ dairy cows of mixed parity (primiparous $=27$, second lactation $=10$, and third lactation and above $=11$ ) in their early- to mid-lactation period, averaging (mean \pm SD) $103 \pm 33.5$ DIM, 623 $\pm 72.7 \mathrm{~kg}$ of $\mathrm{BW}$, and $32.6 \pm 7.7 \mathrm{~kg}$ milk yield at the beginning of the experiment were used in a completely randomized block design (Figure 1). All animals had free access to the same grass silage, prepared from primary growth using a bunker silo, for a period of $70 \mathrm{~d}$. Chemical composition of the grass silage is presented in Table 1. The silage was distributed through 40 automatic feeders (BioControl AS) equipped with vertically moving gates with electronic cow identification and feed intake registration for each individual cow. All cows had free access to the 40 automatic feeders. The feed troughs were filled twice every day (between 0800 and $1000 \mathrm{~h}$, and between 1500 and $1600 \mathrm{~h}$ ) with fresh grass silage. The silage was chopped using a Siloking chopping and mixing machine (DUO1814, Siloking Kverneland, Kverneland Group Ireland Ltd.) until uniform mixture and particle length was achieved, to restrict feed selection by cows.

The first $14 \mathrm{~d}$ were considered a covariate period, during which all 48 cows were fed a soybean-based concentrate feed (SBM) in addition to grass silage (Figure 1). The ratio between grass silage and concentrate was 39:61 (CP and NDF shown in Table 1). The amount of concentrate feed for each animal was calculated to meet requirements for maintenance and production at the start of the experiment using the NorFor feeding system (TINE OptiFôr; NorFor, 2011).

At the end of the covariate period, the 48 cows were randomly assigned to 1 of 3 treatment groups blocked for parity (i.e., first and second or greater lactation) and balanced for DIM and milk yield, giving 16 cows in each treatment group. The groups were then randomly allocated to 1 of the 3 different concentrate feeds: SBM (continuation of covariate period feeding), yeast (YEA), or barley (BAR; see Figure 1 for experimental layout). The SBM concentrate feed contained 7.0\% (on DM basis) soybean meal. This was quantitatively replaced by yeast and barley in the YEA and BAR 


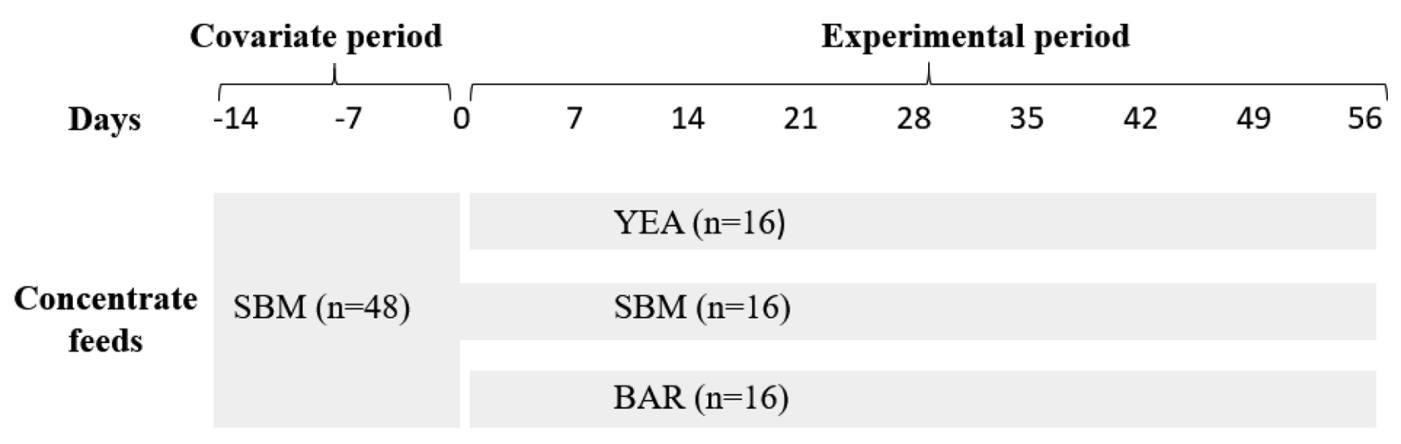

Grass silage

Ad libitum access from automatic feeders

Figure 1. Schematic of the experiment, with dairy cows fed grass silage augmented with 3 different concentrate feeds, where soybean meal (SBM) was substituted with either yeast protein from Cyberlindnera jadinii (YEA) or barley (BAR) over an experimental period of 56 d.

concentrate feeds, respectively. Ingredient and chemical compositions of the feeds used are provided in Table 1, whereas data on AA composition of the feeds are provided in Table 2. The yeast protein was supplied by Lallemand (produced by Danstar Ferment A.G.), and all concentrate feeds were prepared at Felleskjøpet Agri (FKA, Vestnes, Norway). A brief summary of the chemical composition of $C$. jadinii is provided in the footnotes of Table 1. All 3 concentrate feeds were formulated to be isoenergetic (Table 1). The SBM and YEA concentrate feeds were formulated to be isonitrogenous, whereas the BAR concentrate feed was formulated to ensure the dietary protein supply needed for the goodquality grass silage. The concentrate feeds were offered in split portions daily, maximum of $4 \mathrm{~kg}$ per cow per visit, from 3 FSC40 DeLaval feeding stations, with additional small portions $(\sim 1.0 \mathrm{~kg}$ of SBM split over 3 visits) fed in a milking robot. All cows had free access to their feeding stations. The level of concentrate feeds offered was adjusted twice over the experimental period (reduced $15 \%$ on d 28 , and an additional $10 \%$ on d 50 , relative to covariate-period feeding) for all groups, to account for the increasing stage of lactation and declining yield.

Individual feed intake of grass silage and concentrate feeds as well as milk yield were measured daily for 70 d. The cows were housed in a freestall with concrete slatted floors and lying cubicles with rubber mats and sawdust bedding. Cow BW and BCS (on a scale from $1.0=$ emaciated to $5.0=$ obese) were recorded multiple times $($ mean $=2.5 ; \mathrm{SD}=0.85)$ per cow per day when cows visited the milking robot. The BCS was recorded by a DeLaval BCS camera mounted on a DeLaval sort gate (DeLaval VMS Classic). The camera took a 3-dimensional image of the lower back of cows, which was then analyzed with DeLaval BCS software, determining the amount of fat covering the loin, rump tailhead, hooks, pins, and short ribs to calculate the automated BCS, as recently described by Mullins et al. (2019). The BW of cows was recorded just after milking with a BioControl weighing scale (BioControl AS). Changes in $\mathrm{BW}$ and BCS over the experimental period, calculated as the difference between mean BW and BCS in the last week of the experiment (i.e., d 50-56) relative to the covariate period BW and BCS, in respective order, were later used in the statistical analysis.

\section{Feed Sampling and Analyses}

About $400 \mathrm{~g}$ of each of the 3 concentrate feeds and $500 \mathrm{~g}$ of grass silage samples were taken once every week and stored at $-20^{\circ} \mathrm{C}$ pending further processing. At completion of the experiment, the grass silage samples were pooled at 3 time points (i.e., covariate period, first $28 \mathrm{~d}$, and last $28 \mathrm{~d}$ of the experimental period), whereas the concentrate feeds were pooled at the latter 2 time points. The samples were then dried in duplicates at $45^{\circ} \mathrm{C}$ for $48 \mathrm{~h}$ in preparation for milling. The duplicates were mixed and milled using a cutting mill (SM 200, Retsch $\mathrm{GmbH}$ ) at different sieve sizes for the planned analyses as subsequently described.

Concentrate feed samples for starch analysis were milled through a 0.5 -mm sieve, whereas both concentrate feed and silage samples for other analysis were milled through a $1.0-\mathrm{mm}$ sieve. The DM content of the samples was determined by drying at $103^{\circ} \mathrm{C}$ overnight (ISO, 1999), whereas the ash content was determined by incinerating the samples at $550^{\circ} \mathrm{C}$ (ISO, 2002). The nitrogen content of the feeds was analyzed using AOAC method 2001.11 (Thiex et al., 2002), with a Kjeltec 2400/2460 Auto Sampler System (Foss Analytical). Total starch content of the concentrate feed samples was analyzed using AACC method 76-13.01 (Megazyme amyloglucosidase $/ \alpha$-amylase method; AACC, 2000) 
Table 1. Ingredients (\%, DM basis) and chemical composition of grass silage and 3 concentrate feeds (SBM = soybean meal-based; YEA = yeast-based; BAR = barley-based, with barley replacing both yeast and soybean meal)

\begin{tabular}{|c|c|c|c|c|}
\hline Item & $\begin{array}{l}\text { Grass } \\
\text { silage }\end{array}$ & $\mathrm{SBM}$ & YEA & BAR \\
\hline \multicolumn{5}{|l|}{ Ingredient composition } \\
\hline Barley & & 48.9 & 49.2 & 55.4 \\
\hline Corn gluten meal & & 2.14 & 2.13 & 2.15 \\
\hline Oat & & 4.94 & 4.93 & 4.97 \\
\hline Wheat & & 9.89 & 9.85 & 9.94 \\
\hline Molasses & & 4.20 & 4.19 & 4.23 \\
\hline Beet pulp & & 15.3 & 15.3 & 15.4 \\
\hline Soybean meal & & 7.00 & — & - \\
\hline Yeast $^{1}$ & & - & 7.29 & - \\
\hline Calcium soap of fatty acids ${ }^{2}$ & & 3.38 & 3.04 & 3.29 \\
\hline Limestone & & 0.30 & 0.53 & 0.31 \\
\hline Monocalcium phosphate & & 0.66 & 0.37 & 0.77 \\
\hline Sodium bicarbonate & & 1.16 & 1.27 & 1.35 \\
\hline Magnesium oxide & & 0.51 & 0.51 & 0.51 \\
\hline Sodium sulfate & & 0.12 & 0.03 & 0.20 \\
\hline Salt $(\mathrm{NaCl})$, feed-grade & & 1.00 & 1.00 & 1.01 \\
\hline Micromineral premix ${ }^{3}$ & & 0.11 & 0.11 & 0.11 \\
\hline Selenpremiks ${ }^{4}$ & & 0.14 & 0.14 & 0.15 \\
\hline Vitamin premix ${ }^{5}$ & & 0.09 & 0.09 & 0.09 \\
\hline Agolin Ruminant $^{6}$ & & 0.07 & 0.07 & 0.07 \\
\hline \multicolumn{5}{|c|}{ Chemical composition $^{7}$ and energy value } \\
\hline DM content $(\mathrm{g} / \mathrm{kg})$ & 300 & 875 & 881 & 875 \\
\hline $\mathrm{CP}$ & 181 & 161 & 157 & 134 \\
\hline $\mathrm{NDF}^{8}$ & 522 & 175 & 169 & 174 \\
\hline Fat & 46.3 & 38.3 & 36.9 & 38.0 \\
\hline Starch & - & 385 & 365 & 406 \\
\hline Ash & 75.8 & 65.9 & 67.5 & 69.2 \\
\hline FPF $^{9}$ & 99.9 & - & - & - \\
\hline $\mathrm{WSC}^{10}$ & 16.7 & 61.5 & 58.5 & 56.8 \\
\hline Residual $\mathrm{CHO}^{11}$ & 58.4 & 113 & 146 & 122 \\
\hline $\mathrm{NE}_{\mathrm{L}}(\mathrm{MJ} / \mathrm{kg} \text { of } \mathrm{DM})^{12}$ & 6.6 & 7.1 & 7.1 & 7.0 \\
\hline
\end{tabular}

${ }^{1}$ Cyberlindnera jadinii yeast (composition on DM basis): $\mathrm{CP}(\mathrm{N} \times 6.25) 479 \mathrm{~g} / \mathrm{kg}$; ash $69 \mathrm{~g} / \mathrm{kg}$; crude fat $54 \mathrm{~g} /$ $\mathrm{kg}$; total carbohydrates $397 \mathrm{~g} / \mathrm{kg}$; and macrominerals P $14.4 \mathrm{~g} / \mathrm{kg}, \mathrm{Na} 0.86 \mathrm{~g} / \mathrm{kg}, \mathrm{Mg} 1.34 \mathrm{~g} / \mathrm{kg}$, and Ca 1.03 $\mathrm{g} / \mathrm{kg}$.

${ }^{2}$ Calcium soap of palm fatty acids provided as Akofeed Kalkfett (AAK).

${ }^{3}$ Micromineral premix (mg/kg of feed): $19.3 \mathrm{Cu}$; $0.25 \mathrm{Co} ; 5.3 \mathrm{I} ; 86 \mathrm{Zn} ; 40 \mathrm{Mn}$; and $100 \mathrm{Fe}$.

${ }^{4}$ Selenium premix (Vilomix) providing $0.4 \mathrm{mg}$ Se per $\mathrm{kg}$ of feed.

${ }^{5}$ Vitamin premix providing 5,004 IU of vitamin A, 2,010 IU of vitamin D, and $80 \mathrm{mg}$ of vitamin E per kilogram of feed.

${ }^{6}$ Agolin Ruminant is a feed additive produced by Agolin SA; https://agolin.ch/.

${ }^{7}$ Mean values for chemical composition are based on a minimum of triplicate analysis.

${ }^{8} \mathrm{NDF}$ in feeds corrected for ash.

${ }^{9} \mathrm{Sum}$ of fermentation products (silage fermentation acids and alcohols).

${ }^{10}$ Water-soluble carbohydrates in feeds.

${ }^{11}$ Calculated residual carbohydrates (difference between DM content and sum of all analytical values) according to NorFor (2011).

${ }^{12}$ Estimated $\mathrm{NE}_{\mathrm{L}}$ at $20 \mathrm{~kg}$ of DMI (NorFor, 2011).

with starch hydrolyzed to glucose and determining the concentration of glucose colorimetrically using an RX DaytoNa ${ }^{+}$spectrophotometer (Randox Laboratories Ltd.). The content of NDF was determined with an Ankom 220 fiber analyzer (Ankom Technology) according to Mertens (2002), using sodium sulfite and $\alpha$-amylase, and further corrected for residual ash. Water-soluble carbohydrate content was determined as described in Randby et al. (2010), whereas residual carbohydrate content was determined as the difference between DM and analytical components (sum of starch, CP, NDF, crude fat, and ash for concentrate feeds, with additional adjustment for silage fermentation products for the grass silage) according to the Nordic feed evaluation system (NorFor, 2011). The AA contents (except for tryptophan; not analyzed) of the silage and concentrate feeds were determined by ion-exchange chromatography according to commission regulation no. 152/2009 
of the European Communities (EC, 2009; Table 2). Silage fermentation products and ammonia nitrogen were analyzed on fresh silage samples at Eurofins (Eurofins Agro Testing Norway AS, Moss, Norway) as recently described by Randby et al. (2020).

\section{Ruminal Fluid Samples}

Ruminal fluid samples were taken from all animals at 3 time points: at the end of the covariate period (d -2 to 0 ), at the middle of the experimental period (d 26-28), and at the end of the experimental period (d 54-56; see Figure 1 for explanation of days). Each sampling point constituted 3 consecutive days (covering all 48 cows) with roughly one-third of the cows in each group included per sampling day. The cows within each feeding group were randomly assigned to 1 of 3 sampling days for the first sampling, and the same groupings were used accordingly for the later samplings. On the sampling days, the cows were moved to the holding area before the morning feed distribution (between 0800 and $0830 \mathrm{~h}$ ). The samples were taken between 0900 and $1030 \mathrm{~h}$ by aspiration using manually operated esophageal tubing (Akselsens Agenturer A/S) fitted with a perforated steel endpoint to restrict suction of large particles. The first portion of the ruminal fluid (approximately 200-300 mL) was discarded to avoid saliva contamination, and an equivalent volume was withdrawn for analysis. This was strained through 4 layers of cheesecloth, and $9.5 \mathrm{~mL}$ was preserved with

Table 2. Amino acid composition ( $\%$ of total AA) and total AA content of grass silage and the 3 concentrate feeds $(\mathrm{SBM}=$ soybean meal-based; YEA = yeast-based; BAR = barley-based)

\begin{tabular}{lcccc}
\hline Amino acid & $\begin{array}{c}\text { Grass } \\
\text { silage }\end{array}$ & SBM & YEA & BAR \\
\hline Ala & 7.97 & 4.33 & 4.87 & 4.48 \\
Arg & 4.26 & 5.59 & 5.03 & 5.01 \\
Asp & 12.3 & 8.11 & 7.58 & 6.95 \\
Cys & 0.77 & 1.72 & 1.61 & 1.84 \\
Glu & 13.4 & 26.7 & 26.9 & 28.6 \\
Gly & 5.31 & 3.72 & 3.78 & 3.71 \\
His & 2.40 & 2.70 & 2.60 & 2.64 \\
Ile & 5.09 & 3.98 & 4.07 & 3.81 \\
Leu & 9.04 & 8.19 & 8.26 & 8.31 \\
Lys & 6.19 & 4.22 & 4.34 & 3.67 \\
Met & 1.62 & 1.31 & 1.33 & 1.39 \\
Phe & 5.75 & 5.41 & 5.20 & 5.03 \\
Pro & 7.18 & 9.24 & 8.90 & 10.6 \\
Ser & 4.63 & 4.69 & 4.75 & 4.60 \\
Thr & 5.30 & 3.77 & 4.12 & 3.69 \\
Tyr & 3.03 & 2.10 & 2.21 & 1.24 \\
Val & 5.73 & 4.25 & 4.49 & 4.37 \\
Total AA ${ }^{1}$ & 115.1 & 124.5 & 114.6 & 100.2 \\
\hline
\end{tabular}

${ }^{1}$ Total amino acid content of the feeds (g/kg of DM) excluding Trp, which was not analyzed.
$0.5 \mathrm{~mL}$ of concentrated formic acid (98\%; vol/vol) and stored in a cold room $\left(4^{\circ} \mathrm{C}\right)$ until completion of the experiment. The $\mathrm{pH}$ of the remaining ruminal fluid was measured using a digital pH 3310 meter (Xylem Analytics Germany $\mathrm{GmbH}$ ). The stored samples were later analyzed for ruminal fluid VFA by GC (TRACE 1300 Gas Chromatograph equipped with a StabilwaxDA column, $3 \mathrm{~m}$, 0.53-mm internal diameter, $0.25 \mu \mathrm{m}$; Thermo Scientific) and for ruminal fluid ammonia-N using AOAC method 2001.11 (Thiex et al., 2002) with a modification that block digestion was not carried out.

\section{Milk Yield and Milk Sample Registration}

The cows were milked using a robotic milking system (DeLaval VMS Classic) with the minimal milking interval set to $5.5 \mathrm{~h}$. Daily milk yield was summed from multiple milkings (mean $\pm \mathrm{SD}: \mathrm{SBM}=2.86 \pm 0.66$, $\mathrm{YEA}=2.64 \pm 0.70$, and $\mathrm{BAR}=2.80 \pm 0.75)$ per cow per day. Milk samples were taken at the end of the covariate period (i.e., d 0), and on d 14, 28, 35, and 56 of the experimental period. On the milk sampling days, 1 composite milk sample per cow was taken from 1900 $\mathrm{h}$ to $0700 \mathrm{~h}$ the next morning. The samples were preserved with a bronopol tablet (2-bromo-2-nitropane-1,3 diol, Broad-Spectrum Microtabs II, Advanced Industries Inc.) and stored in a cold room $\left(4^{\circ} \mathrm{C}\right)$ until analysis for milk protein, fat, lactose, and urea using a Bentley FTS/FCM instrument (Bentley Instruments Inc.). The ECM yield over the experimental period was calculated for each individual cow based on mean milk chemical composition and milk yield according to Sjaunja et al. (1991).

\section{Statistical Analysis}

One cow from the BAR group had mastitis during the experimental period and was separated from the group until she completed medication (i.e., $14 \mathrm{~d}$ ). No data collected on this cow for this period were included in the statistical analysis. The data were analyzed using the PROC MIXED procedure of SAS (SAS for Windows 9.4; SAS Institute Inc.). The respective variables from the covariate period ( $\mathrm{d}-14$ to 0$)$ were used as covariates. The covariate structure that minimized Akaike's information criterion was used, primarily Toeplitz, compound symmetry, or autoregressive. Cow (diet $\times$ parity) was considered a repeated subject in all models. The full model for the effect of different concentrate feeds on feed intake variables, milk yield, milk component yields, and milk $\mathrm{N}$ efficiency (NUE, expressed as $\mathrm{N}$ secreted in milk as a percentage of $\mathrm{N}$ intake) was as follows: 


$$
\begin{aligned}
\mathrm{Y}_{\mathrm{ijkl}}=\mu & + \text { Diet }_{\mathrm{i}}+\text { Day }_{\mathrm{j}}+\text { Parity }_{\mathrm{k}}+\left(\text { Diet } \times \text { Day }_{\mathrm{ij}}\right. \\
& +\mathrm{DIM}+\operatorname{cov}_{\mathrm{ikl}}+\text { Cow }_{\mathrm{ikl}}+\mathrm{e}_{\mathrm{ijkl}},
\end{aligned}
$$

where $Y_{\mathrm{ijkl}}=$ response variable (e.g., milk yield); $\mu=$ overall mean; Diet $_{i}=$ fixed effect of concentrate feed type (i.e., BAR, SBM, YEA); Day $_{\mathrm{j}}=$ fixed effect of day of measurement $(\mathrm{j}=1-56) ;$ Parity $_{\mathrm{k}}=$ fixed effect of parity $(\mathrm{k}=$ primiparous or multiparous $) ; \mathrm{DIM}=$ effect of days in lactation of each individual cow at the start of the covariate period; $\operatorname{cov} \mathrm{X}_{\mathrm{ikl}}=$ effect of covariate period data for each cow within diet and parity (e.g., covariate period milk yield for milk yield data); (Diet $\times$ Day $)_{\mathrm{ij}}=$ interaction effect of concentrate feed type and day of measurement; $\mathrm{Cow}_{\mathrm{ikl}}=$ random effect of cow nested within diet and parity $(1=1-16)$; and $\mathrm{e}_{\mathrm{ijkl}}=$ residual error. Models for VFA and ruminal fluid $\mathrm{pH}$ also included the number of minutes since the last feeding occasion. The effects of dietary treatments on BW and BCS changes were tested using the general linear model in SAS (PROC GLM) with diet, parity, DIM, and covariate period $\mathrm{BW}$ and $\mathrm{BCS}$ values included in their respective model. Tukey-Kramer was used to test for differences between means. Data are presented as least squares means, with statistical significance declared at $P \leq 0.05$ and tendencies discussed at $0.05<P<0.1$.

\section{RESULTS}

\section{Intake, BCS, and BW}

Data on daily DM and nutrient intake are presented in Table 3. Daily total DMI, silage DMI, concentrate feed DMI, and NDF intake were not affected by the dietary treatment (i.e., concentrate feed type). Cows in all 3 dietary treatments achieved a similar level of NDF intake per unit BW $(13.8 \pm 0.29 \mathrm{~g} / \mathrm{kg}$ of $\mathrm{BW})$. However, total starch intake was higher and total dietary $\mathrm{CP}$ intake was lower in the BAR group. The proportions of silage and concentrate feed in the DMI of all groups were calculated to be roughly $65 \%$ and $35 \%$, respectively.

The effect of dietary treatments on BW change was not significant, although BW increased over the experimental period $(22.3,29.8$, and $25.4 \mathrm{~kg}$ in SBM, YEA, and BAR, respectively) over the experimental period. Similarly, BCS change was not affected by the dietary treatments over the experimental period.

\section{Rumen Fermentation Products}

Data on rumen fermentation characteristics are presented in Table 4. Dietary treatment did not influence ruminal ammonia nitrogen, total ruminal fluid VFA, or molar proportions of individual VFA. All ruminal fermentation parameters were affected $(P<0.04)$ by sampling day, except the molar proportion of butyrate. As a result, total ruminal fluid VFA and molar proportions of acetate were higher in the middle of the experimental period than at the end. Conversely, ruminal fluid ammonia nitrogen concentration, molar proportions of propionate, valerate, isobutyrate, and isovalerate were lower in the middle than at the end of the experimental period. The effects of dietary treatments on ruminal fluid $\mathrm{pH}$, acetate-to-propionate ratio, and non-glucogenic to glucogenic VFA ratio were not significant. These variables were significantly higher on samples taken in the middle than at the end of the experimental period.

\section{Milk Yield, Milk Composition, and Component Yields}

Data on milk yield, milk composition, and component yields are presented in Table 5. Both daily milk yield and ECM yield were not affected by the dietary treatments. Similarly, milk fat and lactose contents did not differ among the dietary treatments, but a significant interaction effect of sampling day by treatment was found for milk fat content $(P<0$. 01). This was observed with YEA showing the highest fat content (mean \pm SEM, g/kg of milk: YEA $=45.1 \pm 0.79 ;$ SBM $=43.7 \pm 0.82 ; \mathrm{BAR}=44.2 \pm 0.80)$ with samples taken on d 35. Furthermore, milk protein content $(P=0.10)$ and MUN $(P=0.06)$ were marginally lower in the BAR group than in the other 2 dietary groups. Milk component yields and dietary NUE were not affected by the dietary treatments.

\section{DISCUSSION}

For most parameters, a significant effect of day was observed. This effect is most likely due to the change in amount of concentrate at d 28 and 50. Except for fat concentration in milk, no diet day interaction was observed, and the day effect is not further discussed.

\section{Feed Intake}

Feed intake was not affected by substituting yeast or barley for soybean meal in dairy cow diets. The concentrate feeds were offered in restriction based on individual cow requirements as calculated by NorFor, the Nordic feed evaluation system (TINE OptiFôr; NorFor, 2011), and hence were expected to remain similar between the groups. However, grass silage was offered ad libitum, allowing variations in DMI between cows based on individual cow intake capacity. Despite this, the ratio of silage to total DMI remained similar between the groups. Previous studies with yeast-based 
Table 3. Feed and nutrient intake with dairy cows fed grass silage augmented with 3 different concentrate feeds containing soybean meal (SBM), yeast (YEA), and barley (BAR)

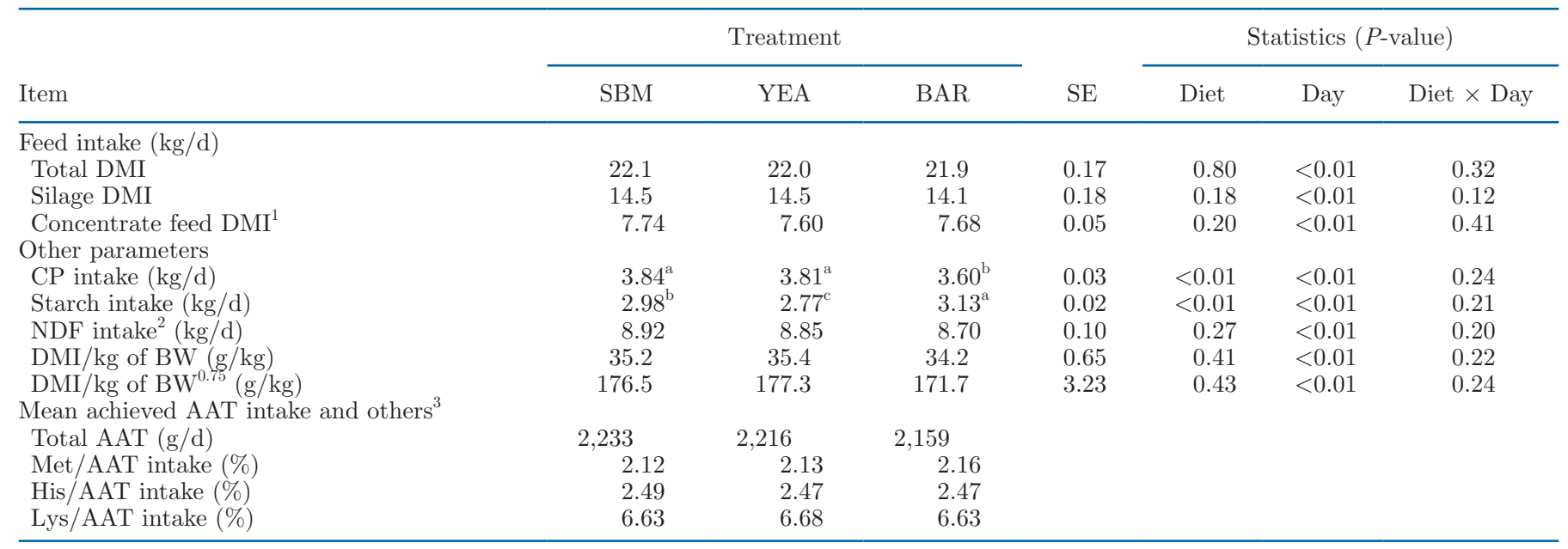

${ }^{\mathrm{a}-\mathrm{c}}$ Different superscript letters within a row indicate significant differences between treatments at $P \leq 0.05$.

${ }^{1}$ The concentrate feeds were offered in split portions, maximum of $4 \mathrm{~kg}$ per cow per visit, each day from 3 DeLaval FSC40 feeding stations, with additional small portions ( $\sim 1.0 \mathrm{~kg}$ of SBM split over 3 visits $)$ fed in a milking robot.

${ }^{2} \mathrm{NDF}$ in the feed corrected for ash.

${ }^{3}$ Estimated achieved total amino acids absorbed in the intestine (AAT) and intakes of Met, Lys, and His as percentage of the total AAT calculated using NorFor feeding standards (TINE OptiFôr; NorFor, 2011) at a diet level.

protein on dairy cow diets produced mixed results. Neal et al. (2014) reported decreased intake of DM and nutrients with dairy cows fed total mixed ration supplemented with yeast-based microbial protein (YMP). They stated that the observed effect was unexpected and was difficult to explain. With dairy cows fed high-forage diets containing increasing levels of YMP (i.e., 0, 1.14, 2.28, and 3.41\% DM of YMP replacing soybean meal), Sabbia et al. (2012) reported a cubic response on DMI over the YMP inclusion range, with the $2.28 \%$ YMP inclusion level producing DMI similar to the control diet. This is comparable to our YEA diet (about $7.0 \%$ yeast in the concentrate feed, which constituted $35 \%$ of the achieved DMI, producing approximately $2.45 \%$ inclusion of yeast in the total diet). In our study, because all the concentrate feeds were roughly isoenergetic, and cows were fed one quality silage over the experimental period, energy intake would not have differed between the groups. Furthermore, the early-cut grass silage used here was above average quality based on the chemical composition (e.g., high in $\mathrm{CP}$ and intermediate in $\mathrm{NDF}$ ), and hence intake limitation due to rumen fill would have been minimal. Indeed, dietary NDF is heterogeneous in nature, and

Table 4. Ruminal fermentation parameters from dairy cows fed grass silage augmented with 3 different concentrate feeds from soybean meal $(\mathrm{SBM})$, yeast (YEA), and barley (BAR)

\begin{tabular}{|c|c|c|c|c|c|c|c|}
\hline Item & \multicolumn{3}{|c|}{ Treatment } & $\mathrm{SE}$ & \multicolumn{3}{|c|}{ Statistics ( $P$-value) } \\
\hline $\mathrm{NH}_{3}-\mathrm{N}(\mathrm{mg} / \mathrm{L})$ & 79.5 & 74.8 & 91.0 & 15.3 & 0.66 & $<0.01$ & 0.23 \\
\hline \multicolumn{8}{|c|}{ Individual VFA (molar \% of total VFA) } \\
\hline Acetate & 66.9 & 65.2 & 64.6 & 1.0 & 0.44 & $<0.01$ & 0.54 \\
\hline Propionate & 16.8 & 17.9 & 17.9 & 0.89 & 0.74 & 0.01 & 0.66 \\
\hline Isobutyrate & 0.85 & 0.83 & 0.87 & 0.032 & 0.68 & $<0.01$ & 0.40 \\
\hline Isovalerate & 1.03 & 1.02 & 1.09 & 0.054 & 0.47 & $<0.01$ & 0.52 \\
\hline Ruminal fluid pH & 7.21 & 6.80 & 6.87 & 0.094 & 0.11 & $<0.01$ & 0.67 \\
\hline Acetate:propionate & 3.99 & 3.67 & 3.64 & 0.027 & 0.73 & $<0.01$ & 0.48 \\
\hline $\mathrm{NGR}^{1}$ & 5.15 & 4.85 & 4.85 & 0.032 & 0.82 & $<0.01$ & 0.54 \\
\hline
\end{tabular}

${ }^{1}$ Non-glucogenic to glucogenic VFA ratio, calculated according to Morvay et al. $(2011)$ as [acetate $+(2 \times$ butyrate $)+(2 \times$ branched-chain VFA)]/[propionate + branched-chain VFA]. 
Table 5. Milk yield, milk composition, milk component yields and dietary milk nitrogen efficiency from dairy cows fed grass silage augmented with 3 different concentrate feeds containing protein from soybean meal (SBM), yeast (YEA), and barley (BAR)

\begin{tabular}{|c|c|c|c|c|c|c|c|}
\hline \multirow[b]{2}{*}{ Item } & \multicolumn{3}{|c|}{ Treatment } & \multirow[b]{2}{*}{$\mathrm{SE}$} & \multicolumn{3}{|c|}{ Statistics ( $P$-value) } \\
\hline & SBM & YEA & BAR & & Diet & Day & Diet $\times$ Day \\
\hline Milk yield $(\mathrm{kg} / \mathrm{d})$ & 30.8 & 30.0 & 29.7 & 0.45 & 0.20 & $<0.01$ & 0.62 \\
\hline $\operatorname{ECM}^{1}(\mathrm{~kg} / \mathrm{d})$ & 32.6 & 32.8 & 31.6 & 0.58 & 0.32 & $<0.01$ & 0.66 \\
\hline \multicolumn{8}{|l|}{ Milk composition } \\
\hline Fat $(\mathrm{g} / \mathrm{kg})$ & 43.7 & 45.1 & 44.2 & 0.81 & 0.45 & $<0.01$ & $<0.01$ \\
\hline MUN (mg/dL) & 14.7 & 14.8 & 14.2 & 0.19 & 0.06 & $<0.01$ & 0.13 \\
\hline \multicolumn{8}{|c|}{ Milk component yields } \\
\hline Fat $(\mathrm{kg} / \mathrm{d})$ & 1.32 & 1.36 & 1.31 & 0.031 & 0.56 & $<0.01$ & 0.32 \\
\hline Protein (kg/d) & 1.09 & 1.09 & 1.04 & 0.024 & 0.23 & $<0.01$ & 0.24 \\
\hline Lactose $(\mathrm{kg} / \mathrm{d})$ & 1.48 & 1.44 & 1.42 & 0.022 & 0.26 & $<0.01$ & 0.19 \\
\hline $\mathrm{NUE}^{3}$ & 28.4 & 28.5 & 29.5 & 0.49 & 0.24 & $<0.01$ & 0.16 \\
\hline
\end{tabular}

${ }^{1} \mathrm{ECM}=$ milk yield $(\mathrm{kg}) \times[(38.3 \times$ fat $(\mathrm{g} / \mathrm{kg})+24.2 \times$ protein $(\mathrm{g} / \mathrm{kg})+16.54 \times$ lactose $(\mathrm{g} / \mathrm{kg})+20.7) / 3,140]$, according to Sjaunja et al. $(1991)$.

${ }^{2}$ Milk true protein.

${ }^{3} \mathrm{NUE}=$ gross dietary milk nitrogen efficiency (nitrogen secreted in milk as a percentage of nitrogen intake).

equating rumen NDF pool based on NDF intake has limitations (Huhtanen et al., 2016). Here, over $97.5 \%$ of the NDF intake originated from a common NDF pool (65\% from the common grass silage, and $32.5 \%$ from the concentrate feed component, as barley, yeast, and soybean meal substitutions accounted for about 7.0\% of the concentrate feed ingredients). Therefore, NDF intake expressed per kilogram of BW could be used as an indicator of rumen fill (NorFor, 2011; Huhtanen et al., 2016). To this end, calculated NDF intake per kilogram of BW was similar between the treatments.

\section{Ruminal Fluid VFA and $\mathrm{pH}$}

Marked changes in the molar proportions of the concentrations of VFA in the ruminal fluid can be observed in response to dietary manipulations (Chalupa, 1977; Sutton et al., 2003). Here, we did not observe any difference between the 3 dietary treatments on ruminal fluid VFA. The observed VFA levels were lower than those reported for dairy cows fed nonrestrictive diets (Sabbia et al., 2012; Neal et al., 2014; Kidane et al., 2018). It has been reported that method of sampling (i.e., via rumen canula vs. esophageal tubing) could affect the total VFA content, with esophageal tubing underestimating the VFA content (Raun and Burroughs, 1962; Geishauser and Gitzel, 1996; Shen et al., 2012; van Gastelen et al., 2019). However, the molar percentages of specific VFA have been reported to be unbiased by the method of sampling (Raun and Burroughs, 1962; van Gastelen et al., 2019) and also were not influenced by the dietary treatments in our experiment. Furthermore, ruminal fluid acetate-to-propionate ratio and non-glucogenic to glucogenic VFA ratio were not altered by the dietary treatments. For both ratios, the values are higher than those observed in cows fed TMR (Kidane et al., 2018) using samples taken at multiple time points over a 24 -h cycle.

Ruminal fluid $\mathrm{pH}$ was not affected by the dietary treatments, despite our expectation that the BAR diet would decrease rumen $\mathrm{pH}$ compared with the other treatments because of increased and rapid starch degradation (Nikkhah, 2012). Ruminal fluid $\mathrm{pH}$ usually oscillates depending upon, among other factors, meals and feeding times (Palmonari et al., 2010; Kidane et al., 2018). Our samples were collected before morning feeding, and the observed elevated ruminal fluid $\mathrm{pH}$ would suggest low VFA concentration, due to active uptake and reduced fermentable $\mathrm{OM}$ in the rumen. High ruminal fluid $\mathrm{pH}$ could also be partly due to saliva contamination (Grünberg and Constable, 2009), despite our attempts to avoid this.

\section{Milk Yield, Milk Composition, and Milk Nitrogen Efficiency}

Milk yield and milk composition were not affected by the dietary treatments. Achieved dietary CP levels were not restrictive, with the lowest for the BAR group being $164 \mathrm{~g} / \mathrm{kg}$ of DM. With early- to mid-lactation Holstein dairy cows, Law et al. (2009) demonstrated a tendency toward a greater milk yield response when increasing dietary CP from 114 to $144 \mathrm{~g} / \mathrm{kg}$ of DM than from 144 to $173 \mathrm{~g} / \mathrm{kg}$ of DM. Others (Cunningham et al.,1996; Leonardi et al., 2003) observed no improvement in milk yield when dietary $\mathrm{CP}$ increased over a range (e.g., 161-189 g/kg of DM) that contained what was achieved in our experiment. The supply of amino 
acids absorbed in the intestine (AAT) for milk synthesis is mainly contributed by rumen microbial protein and rumen undegraded dietary protein absorbed in the small intestine. These are, in turn, influenced by both rate of protein degradation in the rumen and rate of passage. As a result, differences in the rate of degradation of different types of protein and rate of passage from the rumen make it difficult to compare the bypass protein level of different feeds given comparable dietary CP (Owens and Bergen, 1983). To our knowledge, values of ruminal degradation and passage rate of the yeast protein used here are unknown. Our effort to compare ruminal degradation rates of the yeast protein and soybean meal ingredients using an in sacco technique (38- $\mu \mathrm{m}$ pore size; NorFor, 2011) was not successful because of substantial particle loss (over $80 \%$ on DM basis) upon washing with the yeast protein. Sabbia et al. (2012) speculated that yeast-derived microbial protein would flow with the liquid phase out of the rumen, rendering it some degree of protection due to a high rumen escape rate. This was observed with a linear decrease in ruminal ammonia concentrations with increasing yeast-derived microbial protein in the diets. Our YEA concentrate feed created only numerical difference compared with SBM on ruminal fluid ammonia concentration, failing to support the above hypothesis. However, Owens and Bergen (1983) argued that plant proteins, including soybean, have a higher degree of protein degradation in the rumen compared with other protein sources with a high bypass fraction (e.g., distillers products).

Lysine, methionine, and histidine have been identified most often as the limiting AA for milk production (Schwab and Broderick, 2017). Which AA is the first limiting depends on the feed protein source. Here, calculated dietary intakes of total AAT and these $3 \mathrm{AA}$ fell within a narrow range for all groups, with Lys and Met intake (percentage of AAT) close to milk yields allowable by the achieved AAT intake (NRC, 2001). Thus, the observed milk yield, milk protein content, and protein yield from the SBM and YEA diets suggested that the diets supplied comparable levels of AA absorbed in the small intestine.

It has been reported that His could be the first limiting AA for milk production when grass silage constituted the main part of the diet with barley- and oat-based concentrate feeds (Kim et al., 1999; Schwab et al., 2005). This was more pronounced when rumen microbial protein provided most of the MP supply to the small intestine (Lee et al., 2012). However, the observed numeric differences in milk and milk protein yields between the dietary groups here were not as large as expected. It has been reported that endogenous reserves (e.g., carnosine, anserine, and hemoglobin) can release His to sustain metabolic needs during periods of deficiency (Clemens et al., 1984; Lapierre et al., 2008), indicating some degree of phenotypic plasticity in Hisdeficient diets. Therefore, it can be argued that, only with an extended period of feeding, shortage of dietary His in the BAR diet would have penalized milk protein synthesis.

Furthermore, microbial protein supplies a large portion of the AAT (Storm and Ørskov, 1983; Clark et al., 1992), with an AA profile comparable to that of milk. Thus, increasing the concentration of rumen-fermentable carbohydrates would be expected to influence microbial protein synthesis in the rumen (Meyer et al., 1967) and improve milk production at a given dietary CP intake (Broderick, 2003). Our barley-based diet had higher starch but lower dietary $\mathrm{CP}$ content relative to the SBM and YEA diets. Given the proportion of grass silage in the total DMI and its high CP content (with $550 \mathrm{~g}$ of soluble $\mathrm{CP}$ per $\mathrm{kg}$ of $\mathrm{CP}$ ), and the high starch intake from barley in the concentrate feed, microbial CP synthesis would be expected to be higher (Keady et al., 1998; Cone and Becker, 2012) in the BAR group. Therefore, even with the observed lower CP intake in the group relative to the other 2 diets, it might be that an increased microbial $\mathrm{CP}$ synthesis in the BAR could have compensated for this. This could explain the observed similar milk yield across treatments, in contrast to our hypothesis.

In dairy cow feeding, dietary nitrogen intake, nitrogen secretion in milk, and excretion in manure regulate environmental impacts. As a result, efforts are being made to improve NUE and reduce nitrogen loss. About 25 to $35 \%$ of dietary nitrogen is captured and secreted in milk (Broderick, 2003; Kidane et al., 2018). A large part of the remaining nitrogen is lost in manure, which is undesirable both in terms of cost and from the environment perspective. In our experiment, NUE was numerically higher in the BAR group compared with the others, but the absence of contrasting difference among the dietary treatments could be explained by the narrow range of dietary $\mathrm{CP}$ in the DMI.

\section{CONCLUSIONS}

Our results indicate that yeast can be used as a protein source in diets for early- to mid-lactation NRF dairy cows, without negative effects on milk yield and milk composition. Replacement of soybean meal and yeast with barley, in combination with a grass silage of good quality, showed a tendency for decreased milk protein content. Further research on the long-term effects of these diets, in combination with varying silage qualities, may be required to adequately describe effects on milk production and milk composition, without 
interfering effects of metabolic plasticity in response to changes in nutrient supply.

\section{ACKNOWLEDGMENTS}

We thank the staff members of the Livestock Production Research Center of the Norwegian University of Life Sciences (Ås, Norway) for their help in the trial. We also thank the anonymous reviewers for the critical review, valuable comments, and suggestions, which helped us improve the quality of this manuscript. This work was part of the Foods of Norway Project (Centre for Research-Based Innovation; grant number 237841), funded by the Research Council of Norway (Norges Forskningsråd, Oslo). The concentrate feeds were produced at Felleskjøpet Agri (Felleskjøpet Agri, Lillestrøm, Norway). The authors have not stated any conflicts of interest.

\section{REFERENCES}

Åby, B. A., J. Kantanen, L. Aass, and T. Meuwissen. 2014. Current status of livestock production in the Nordic countries and future challenges with a changing climate and human population growth. Acta Agric. Scand. A Anim. Sci. 64:73-97. https://doi.org/10 $.1080 / 09064702.2014 .950321$.

AACC. 2000. Approved Methods of the AACC. 10th ed. Am. Assoc. Cereal Chem.

Broderick, G. A. 2003. Effects of varying dietary protein and energy levels on the production of lactating dairy cows. J. Dairy Sci. 86:1370-1381. https://doi.org/10.3168/jds.S0022-0302(03)73721 $-7$.

Cavins, J. F., W. F. Kwolek, G. E. Inglett, and J. C. Kowan. 1972. Amino acid analysis of soybean meal: Interlaboratory study. J. AOAC 55:686-691. https://doi.org/10.1093/jaoac/55.4.686.

Chalupa, W. 1977. Manipulating rumen fermentation. J. Anim. Sci. 45:585-599. https://doi.org/10.2527/jas1977.453585x.

Clark, J. H., T. H. Klusmeyer, and M. R. Cameron. 1992. Microbial protein synthesis and flows of nitrogen fractions to the duodenum of dairy cows. J. Dairy Sci. 75:2304-2323. https://doi.org/10 .3168/jds.S0022-0302(92)77992-2.

Clemens, R. A., J. D. Kopple, and M. E. Swendseid. 1984. Metabolic effects of histidine-deficient diets fed to growing rats by gastric tube. J. Nutr. 114:2138-2146. https://doi.org/10.1093/jn/114.11 .2138 .

Cone, J. W., and P. M. Becker. 2012. Fermentation kinetics and production of volatile fatty acids and microbial protein by starchy feedstuffs. Anim. Feed Sci. Technol. 172:34-41. https://doi.org/10 1016/j.anifeedsci.2011.12.006

Cruz, A., H. Sterten, F. S. Steinhoff, L. T. Mydland, and M. Øverland. 2020a. Cyberlindnera jadinii yeast as a protein source for broiler chickens: Effects on growth performance and digestive function from hatching to 30 days of age. Poult. Sci. 99:3168-3178. https:/ /doi.org/10.1016/j.psj.2020.01.023.

Cruz, A., A.-H. Tauson, C. F. Matthiesen, L. T. Mydland, and M. Øverland. 2020b. Cyberlindnera jadinii yeast as a protein source for growing pigs: Effects on protein and energy metabolism. Livest. Sci. 231:103855. https://doi.org/10.1016/j.livsci.2019.103855.

Cunningham, K. D., M. J. Cecava, T. R. Johnson, and P. A. Ludden. 1996. Influence of source and amount of dietary protein on milk yield by cows in early lactation. J. Dairy Sci. 79:620-630. https:// doi.org/10.3168/jds.S0022-0302(96)76407-X.

Dalle Zotte, A., Y. Singh, J. Michiels, and M. Cullere. 2019. Black soldier fly (Hermetia illucens) as dietary source for laying quails:
Live performance, and egg physico-chemical quality, sensory profile and storage stability. Animals (Basel) 9:115. https://doi.org/ 10.3390/ani9030115.

EC (European Communities). 2009. Commission regulation no. 152/2009 of 27 January 2009, laying down the methods of sampling and analysis for the official control of feed. Off. J. Eur. Union L 54:24-27.

Foley, J. A., N. Ramankutty, K. A. Brauman, E. S. Cassidy, J. S. Gerber, M. Johnston, N. D. Mueller, C. O'Connell, D. K. Ray, P. C. West, C. Balzer, E. M. Bennett, S. R. Carpenter, J. Hill, C. Monfreda, S. Polasky, J. Rockström, J. Sheehan, S. Siebert, D. Tilman, and D. P. M. Zaks. 2011. Solutions for a cultivated planet. Nature 478:337-342. https://doi.org/10.1038/nature10452.

Geishauser, T., and A. Gitzel. 1996. A comparison of rumen fluid sampled by oro-ruminal probe versus ruminal fistula. Small Rumin. Res. 21:63-69. https://doi.org/10.1016/0921-4488(95)00810-1.

Government of Norway. 2014. Forestry. Accessed Aug. 2, 2021. https: //www.regjeringen.no/en/topics/food-fisheries-and-agriculture/ skogbruk/innsikt/skogbruk/id2009516/.

Grünberg, W., and P. D. Constable. 2009. Chapter 6: Function and dysfunction of the ruminant forestomach. Pages 12-19 in Food Animal Practice, 5th ed. D. E. Anderson and D. M. Rings, ed. W. B. Saunders.

Higginson, V., B. Baurhoo, Y. Schuermann, M. Taibi, A. St-Yves, R. Duggavathi, and A. Mustafa. 2017. Effects of yeast-derived rumen escape microbial protein on lactational performance and metabolic status of transition dairy cows. J. Anim. Sci. 95(Suppl. 2):39. https://doi.org/10.2527/asasmw.2017.083.

Hristov, A. N., J. K. Ropp, K. L. Grandeen, S. Abedi, R. P. Etter, A. Melgar, and A. E. Foley. 2005. Effect of carbohydrate source on ammonia utilization in lactating dairy cows. J. Anim. Sci. 83:408421. https://doi.org/10.2527/2005.832408x.

Huhtanen, P., E. Detmann, and S. J. Krizsan. 2016. Prediction of rumen fiber pool in cattle from dietary, fecal, and animal variables. J. Dairy Sci. 99:5345-5357. https://doi.org/10.3168/jds.2015-10842.

Huhtanen, P., S. Jaakkola, and J. Nousiainen. 2013. An overview of silage research in Finland: From ensiling innovation to advances in dairy cow feeding. Agric. Food Sci. 22:35-56. https://doi.org/ $10.23986 /$ afsci. 6632 .

ISO. 2002. 5984: Animal feeding stuffs-Determination of crude ash. International Organization for Standardization.

ISO. 1999. 6496: Animal feeding stuffs-Determination of moisture and other volatile matter content. International Organization for Standardization.

Keady, T. W. J., C. S. Mayne, and M. Marsden. 1998. The effects of concentrate energy source on silage intake and animal performance with lactating dairy cows offered a range of grass silages. Anim. Sci. 66:21-33. https://doi.org/10.1017/S1357729800008808.

Kidane, A., M. Øverland, L. T. Mydland, and E. Prestløkken. 2018. Interaction between feed use efficiency and level of dietary crude protein on enteric methane emission and apparent nitrogen use efficiency with Norwegian Red dairy cows. J. Anim. Sci. 96:39673982. https://doi.org/10.1093/jas/sky256.

Kim, C.-H., J.-J. Choung, and D. G. Chamberlain. 1999. Determination of the first-limiting amino acid for milk production in dairy cows consuming a diet of grass silage and a cereal-based supplement containing feather meal. J. Sci. Food Agric. 79:1703-1708. https: //doi.org/10.1002/(SICI) 1097-0010(199909)79:12<1703::AIDJSFA $424>3.0 . \mathrm{CO} ; 2-5$.

Lapierre, H., D. Ouellet, L. Doepel, G. Holtrop, and G. Lobley. 2008. Histidine, lysine and methionine: From metabolism to balanced dairy rations. Pages 14-31 in Proc. Eastern Nutrition Conference of Animal Nutrition Association of Canada. University of Guelph.

Law, R. A., F. J. Young, D. C. Patterson, D. J. Kilpatrick, A. R. Wylie, and C. S. Mayne. 2009. Effect of dietary protein content on animal production and blood metabolites of dairy cows during lactation. J. Dairy Sci. 92:1001-1012. https://doi.org/10.3168/jds .2008-1155.

Lee, C., A. N. Hristov, K. S. Heyler, T. W. Cassidy, H. Lapierre, G. A. Varga, and C. Parys. 2012. Effects of metabolizable protein supply and amino acid supplementation on nitrogen utilization, milk 
production, and ammonia emissions from manure in dairy cows. J. Dairy Sci. 95:5253-5268. https://doi.org/10.3168/jds.2012-5366.

Leonardi, C., M. Stevenson, and L. E. Armentano. 2003. Effect of two levels of crude protein and methionine supplementation on performance of dairy cows. J. Dairy Sci. 86:4033-4042. https://doi.org/ 10.3168/jds.S0022-0302(03)74014-4.

Manthey, A. K., K. F. Kalscheur, A. D. Garcia, and K. Mjoun. 2016. Lactation performance of dairy cows fed yeast-derived microbial protein in low- and high-forage diets. J. Dairy Sci. 99:2775-2787. https://doi.org/10.3168/jds.2015-10014.

Mertens, D. R. 2002. Gravimetric determination of amylase-treated neutral detergent fiber in feeds with refluxing in beakers or crucibles: Collaborative study. J. AOAC Int. 85:1217-1240.

Meyer, R. M., E. E. Bartley, C. W. Deyoe, and V. F. Colenbrander. 1967. Feed processing. I. Ration effects on rumen microbial protein synthesis and amino acid composition. J. Dairy Sci. 50:1327-1332. https://doi.org/10.3168/jds.S0022-0302(67)87624-0.

Morvay, Y., A. Bannink, J. France, E. Kebreab, and J. Dijkstra. 2011. Evaluation of models to predict the stoichiometry of volatile fatty acid profiles in rumen fluid of lactating Holstein cows. J. Dairy Sci. 94:3063-3080. https://doi.org/10.3168/jds.2010-3995.

Mullins, I. L., C. M. Truman, M. R. Campler, J. M. Bewley, and J. H. C. Costa. 2019. Validation of a commercial automated body condition scoring system on a commercial dairy farm. Animals (Basel) 9:287. https://doi.org/10.3390/ani9060287.

Neal, K., J. S. Eun, A. J. Young, K. Mjoun, and J. O. Hall. 2014. Feeding protein supplements in alfalfa hay-based lactation diets improves nutrient utilization, lactational performance, and feed efficiency of dairy cows. J. Dairy Sci. 97:7716-7728. https://doi .org/10.3168/jds.2014-8033.

Nikkhah, A. 2012. Barley grain for ruminants: A global treasure or tragedy. J. Anim. Sci. Biotechnol. 3:22. https://doi.org/10.1186/ 2049-1891-3-22.

NorFor. 2011. NorFor: The Nordic Feed Evaluation System. H. Volden, ed. EAAP Scientific Series, No. 30. Wageningen Academic Publishers.

Notarnicola, B., G. Tassielli, P. A. Renzulli, V. Castellani, and S. Sala. 2017. Environmental impacts of food consumption in Europe. J. Clean. Prod. 140:753-765. https://doi.org/10.1016/j.jclepro.2016 .06 .080 .

NRC. 2001. Nutrient Requirements of Dairy Cattle. 7th ed. National Academy Press.

Øverland, M., and A. Skrede. 2017. Yeast derived from lignocellulosic biomass as a sustainable feed resource for use in aquaculture. J. Sci. Food Agric. 97:733-742. https://doi.org/10.1002/jsfa.8007.

Owens, F. N., and W. G. Bergen. 1983. Nitrogen metabolism of ruminant animals: historical perspective, current understanding and future implications. J. Anim. Sci. 57(Suppl. 2):498-518. https:// doi.org/10.2527/animalsci1983.57Supplement_2498x.

Palmonari, A., D. M. Stevenson, D. R. Mertens, C. W. Cruywagen, and P. J. Weimer. 2010. pH dynamics and bacterial community composition in the rumen of lactating dairy cows. J. Dairy Sci. 93:279-287. https://doi.org/10.3168/jds.2009-2207.

Randby, Å. T., H. N. Halvorsen, and A. K. Bakken. 2020. Losses and grass silage quality in bunker silos compacted by tractor versus wheel loader. Anim. Feed Sci. Technol. 266:114523. https://doi .org/10.1016/j.anifeedsci.2020.114523.

Randby, Å. T., P. Nørgaard, and M. R. Weisbjerg. 2010. Effect of increasing plant maturity in timothy-dominated grass silage on the performance of growing/finishing Norwegian Red bulls. Grass Forage Sci. 65:273-286. https://doi.org/10.1111/j.1365-2494.2010 $.00745 . x$.

Raun, N. S., and W. Burroughs. 1962. Suction strainer technique in obtaining rumen fluid samples from intact lambs. J. Anim. Sci. 21:454-457. https://doi.org/10.2527/jas1962.213454x.
Sabbia, J. A., K. F. Kalscheur, A. D. Garcia, A. M. Gehman, and J. M. Tricarico. 2012. Soybean meal substitution with a yeastderived microbial protein source in dairy cow diets. J. Dairy Sci. 95:5888-5900. https://doi.org/10.3168/jds.2011-5237.

Schwab, C. G., and G. A. Broderick. 2017. A 100-Year Review: Protein and amino acid nutrition in dairy cows. J. Dairy Sci. 100:1009410112. https://doi.org/10.3168/jds.2017-13320.

Schwab, C. G., P. Huhtanen, C. Hunt, and T. Hvelplund. 2005. Nitrogen requirements of cattle. In Nitrogen and Phosphorus Nutrition of Cattle: Reducing the Environmental Impact of Cattle Operations. E. Pfeffer and A. N. Hristov, ed. CABI Publishing.

Sharma, S., L. Hansen, J. Ø. Hansen, L. Mydland, S. Horn, M. Øverland, V. Eijsink, and K. Vuoristo. 2018. Microbial protein produced from brown seaweed and spruce wood as a feed ingredient. J. Agric. Food Chem. 66:8328-8335. https://doi.org/10.1021/acs .jafc. 8 b01835.

Shen, J. S., Z. Chai, L. J. Song, J. X. Liu, and Y. M. Wu. 2012. Insertion depth of oral stomach tubes may affect the fermentation parameters of ruminal fluid collected in dairy cows. J. Dairy Sci. 95:5978-5984. https://doi.org/10.3168/jds.2012-5499.

Sjaunja, L. O., L. Baevre, L. Junkarinen, J. Pedersen, and J. Setälä. 1991. A Nordic proposal for an energy corrected milk (ECM) formula. Pages 156-157 in Performance Recording of Animals: State of the Art, 1990: Proceedings of the 27th Biennial Session of the International Committee for Animal Recording (ICAR), Paris, France. Wageningen Academic Publishers.

Solberg, B., A. Moiseyev, J. Ø. Hansen, S. J. Horn, and M. Øverland. 2021. Wood for food: Economic impacts of sustainable use of forest biomass for salmon feed production in Norway. For. Policy Econ. 122:102337. https://doi.org/10.1016/j.forpol.2020.102337.

Storm, E., and E. Ørskov. 1983. The nutritive value of rumen microorganisms in ruminants: 1. Large-scale isolation and chemical composition of rumen micro-organisms. Br. J. Nutr. 50:463-470. https: //doi.org/10.1079/BJN19830114.

Sutton, J. D., M. S. Dhanoa, S. V. Morant, J. France, D. J. Napper, and E. Schuller. 2003. Rates of production of acetate, propionate, and butyrate in the rumen of lactating dairy cows given normal and low-roughage diets. J. Dairy Sci. 86:3620-3633. https://doi .org/10.3168/jds.S0022-0302(03)73968-X.

Thiex, N. J., H. Manson, S. Anderson, J.-Å. Persson, S. Anderson, E. Bogren, G. Bolek, D. Budde, C. Ellis, S. Eriksson, G. Field, E. Frankenius, C. Henderson, C. Henry, M. Kapphahn, L. Lundberg, H. Manson, J. Moller, M. Russell, J. Sefert-Schwind, and M. Spann. 2002. Determination of crude protein in animal feed, forage, grain, and oilseeds by using block digestion with a copper catalyst and steam distillation into boric acid: Collaborative study. J. AOAC Int. 85:309-317. https://doi.org/10.1093/jaoac/85.2.309.

van Gastelen, S., F. Schumacher, J. W. Cone, J. Dijkstra, and W. F. Pellikaan. 2019. In dairy cattle, the stomach tube method is not a feasible alternative to the rumen cannulation method to examine in vitro gas and methane production. Anim. Feed Sci. Technol. 256:114259. https://doi.org/10.1016/j.anifeedsci.2019.114259.

\section{ORCIDS}

Alemayehu Kidane ๑ https://orcid.org/0000-0003-2945-7189 Stine Gregersen Vhile @ https://orcid.org/0000-0003-1104-2647 Sabine Ferneborg @ (ㄴ) https://orcid.org/0000-0002-9218-9407 Siv Skeie @ https://orcid.org/0000-0003-1928-4085 Martine Andrea Olsen (๑) https://orcid.org/0000-0003-0293-7027 Liv Torunn Mydland ๑ https://orcid.org/0000-0002-9361-3687 Margareth Øverland ๑ https://orcid.org/0000-0003-1142-6624 Egil Prestløkken @ https://orcid.org/0000-0003-3151-6782 